\title{
CORRESPONDENCE
}

\section{Conservation of important geological sites}

SIR,-May I bring to the attention of your readers a problem which is beginning seriously to affect geological teaching and research in Britain and which may become more acute unless action is soon taken?

In recent years it has become apparent that geology in Britain, and to a varying extent also in Europe and North America, faces a new and special type of problem in the conservation or preservation of sites of geological importance. In many ways the science of geology is a comparative one, needing types for its species (fossil and mineral) and formations. Type specimens and sections acquire an importance which may not be permanent but which necessitates their preservation wherever possible. That type localities and sections may become obliterated, restricted or otherwise harmed for the geologist has long been recognized by the Nature Conservancy, the Geological Section of which has done much in invaluably recording, and where necessary negotiating, on behalf of our science. Large scale and rapid excavating techniques make their task more difficult. Recently, too, new hazards have appeared-the careless, indiscriminate and destructive field party and the commercial collector. Of these the former is a cause of much concern to local authorities, land owners and the geological and teaching professions and associations alike. Witness to this are the recent articles in the Jl geol. Soc. Lond. (Toghill, 1972) and Geology (Dineley, 1972) and the setting up of a special committee of the Palaeontological Association. (The Country Code, good though it is, is not concerned with the particular problem of geological sites.)

The Shropshire Conservation Trust has already suggested (Toghill, 1972) some remedial measures for that country. These include the purchase of threatened geological sites by the Trust, the development of alternative sites and the provision of a liaison and information service for would-be users. Stricter discipline of individuals and parties on site is also suggested. These approaches are welcomed by many landowners and quarry operators and better relationships may now in some cases be ensured.

Two other points might be made here. The first is that local groups or schools might actively seek and advertise alternative sites to threatened or over-used localities. Ideally, the local natural history societies, Geologists' Association local groups or conservation bodies, together with educational establishments could embark upon this type of exercise.

Secondly, where alternative sites may not be available, local groups might undertake to conserve the existing heavily used localities.

To schools and university parties the most urgent word is to restrict irresponsible hammering and damage to exposures. Most students do not need to spend much time and energy pulverizing material to understand it, and the activity detracts from the time they can give to observing the visible data. Geology reproduced in its last issue (Vol. 4, March 1973) a letter written in 1935 to this Magazine by E. S. Cobbold which was in effect an appeal for more considerate treatment of exposures in the Church Stretton area.

Much of the material collected is subsequently lost or discarded as litter and is put to little scientific or educational use. Group leaders would do well to advise that searching for perfect fossils is by and large a long, arduous business, sometimes calling for special knowledge or skill. Most students should not attempt it.

Quarry owners and engineering contractors often allow access to new excavations and exposures; and where important features or materials are found enquiries might be made to ensure that they will remain available for some time to come. Again, the local body rather than the individual may be best to handle such immediate negotiations.

Many quarries and pits today offer convenient sites for the disposal of waste of various kinds and as such their value may be great. Geological and educational con-

Geol. Mag. 110 (6), 1973, pp. 565-566. Printed in Great Britain. 
siderations may not sway local authorities when they are requested not to allow such disposal practices. If it is also known that a site attracts the nuisance of geological parties there will indeed be an incentive to fill in and render useless the place in question. It is in the interest of all geologists in this country to ensure that valuable sites are preserved and that proper behaviour in, and use of, these localities is the practice of all concerned. While appropriate action by the individual geologist is to be applauded, the case for establishing the need to conserve geological localities can be made more forcibly if action is taken by the local societies and the national learned institutions. I am sure that these bodies will appreciate being informed when they can help.

\section{References}

Cobbold, E. S. 1935. An Appeal to Field Parties. Geol. Mag. 72, 144.

Dineley, D. L. 1972. Geology at Risk. Geology, 4, 18-20.

Toghill, P. 1972. Geological conservation in Shropshire. $J l$ geol. Soc. Lond., 128, 513-15.

D. L. DINELEY

Department of Geology

University of Bristol

Bristol, BS8 1TR

8th June 1973 